\title{
Main composition of Physalis (Physalis pubescens L.) fruit juice from Egypt
}

\author{
Aly F. El SHEIKHA ${ }^{1,2 \star}$, Georges PIOMBO ${ }^{2}$, Thierry GOLI $^{2}$, Didier MONTET ${ }^{2}$
}

\author{
${ }^{1}$ Minufiya Univ., Fac. Agric., \\ Dep. Food Sci. Technol., \\ 32511 Shibin El Kom, \\ Minufiya Gov., Egypt, \\ elsheikha_aly@yahoo.com \\ ${ }^{2}$ CIRAD, Persyst, UMR \\ QUALISUD, TA B-95 / 16, \\ 34398 Montpellier Cedex 5, \\ France
}

\begin{abstract}
Main composition of Physalis (Physalis pubescens L.) fruit juice from Egypt.
Abstract - Introduction. Physalis has been known for a long time in Egypt. Among unexploited tropical fruits, Physalis is a very promising fruit. Recently, the economic importance of Physalis has risen, due to its high acceptance for local consumption, achieving great success in the African, Latin American and European markets. One of the challenges of recent years has been to participate in the development of Physalis as a commercial crop of economic utility. In order to understand the nutraceutical and medicinal characteristics of Physalis fruits cultivated in Egypt, the biochemical composition of the raw Physalis pubescens juice was determined. Materials and methods. Whole fresh fruits of Physalis pubescens from Egypt were preserved at $-20^{\circ} \mathrm{C}$ for the duration of the experiment. The juice was extracted from Physalis fruits by using a fruit pulper then filtered on cheesecloth to separate seeds and skins. Contents of oil, fatty acids, proteins, amino acids, sugars and minerals of the juice were analyzed, and were compared and discussed in relation to the biochemical composition of other fruits and vegetable oils. Results. Yield of the juice was high (64\%) and it is a rich source of minerals such as potassium $\left(11.32 \mathrm{~g} \cdot 100 \mathrm{~g}^{-1} \mathrm{dm}\right)$, phosphorus $\left(5.55 \mathrm{~g} \cdot 100 \mathrm{~g}^{-1} \mathrm{dm}\right)$, zinc $\left(0.02 \mathrm{~g} \cdot 100 \mathrm{~g}^{-1} \mathrm{dm}\right)$ and boron $\left(0.01 \mathrm{~g} \cdot 100 \mathrm{~g}^{-1} \mathrm{dm}\right)$, polyphenols $\left(76.6 \mathrm{mg} \cdot 100 \mathrm{~mL}^{-1}\right)$ and carotenoids $\left(70 \mu \mathrm{g} \cdot \mathrm{mL}^{-1}\right)$. It contained good amounts of vitamin $\mathrm{C}\left(38.77 \mathrm{mg} \cdot 100 \mathrm{~mL}^{-1}\right)$ and it could be a good potential source of essential amino acids such as isoleucine, valine and tryptophan [(4.2,3.9 and 3.9) $\mathrm{g} \cdot 100 \mathrm{~g}^{-1}$ protein], whose amounts were higher than those recommended by the FAO / WHO / UNU. Additionally, it contains a low amount of oil $\left(1.1 \mathrm{~g} \cdot 100 \mathrm{~g}^{-1} \mathrm{dm}\right)$. Conclusion. Physalis juice should attract great interest because of its composition. Its potential nutraceutical quality could participate in the development of Physalis as a commercial crop. Certain molecules such as antimicrobial molecules and bioactive withanolides, which have the famous ethnomedical and medical effects of Physalis juice, still have to be studied.
\end{abstract}

Egypt / Physalis pubescens / fruits / proximate composition / mineral content / protein content / lipid content / carotenoids / ascorbic acid / polyphenols

\section{Composition principale de jus de fruits de Physalis (Physalis pubescens L.) en provenance d'Égypte.}

Résumé - Introduction. Le Physalis (cerise de terre) est connu depuis longtemps en Egypte. C'est un fruit très prometteur parmi l'ensemble des fruits tropicaux sous-exploités. Récemment, l'importance économique du Physalis a augmenté en raison de sa bonne acceptation dans la consommation locale et de son grand succès en Afrique, Amérique latine et sur les marchés européens. L'un des défis de ces dernières années a été de placer le Physalis au rang de culture commerciale d'utilité économique. Afin de comprendre les caractéristiques nutraceutiques et médicales des fruits de Physalis cultivés en Egypte, nous avons étudié la composition biochimique du jus brut des fruits de $P$. pubescens. Matériel et méthodes. Des fruits frais entiers de $P$. pubescens d'Egypte ont été conservés à $-20{ }^{\circ} \mathrm{C}$ pendant la durée de l'expérimentation. Le jus a été extrait à l'aide d'un dépulpeur de fruits, puis il a été filtré sur gaze pour séparer graines et peaux. Les teneurs en huile, acides gras, protéines, acides aminés, sucres et minéraux des jus ont été évaluées, comparées et discutées en relation avec la composition biochimique d'autres fruits et huiles végétales. Résultats. Le rendement en jus des fruits de P. pubescens a été élevé (64\%); il est riche en minéraux comme le potassium (11,32 $\left.\mathrm{g} \cdot 100 \mathrm{~g}^{-1} \mathrm{~ms}\right)$, le phosphore $\left(5,55 \mathrm{~g} \cdot 100 \mathrm{~g}^{-1} \mathrm{~ms}\right)$, le zinc $\left(0,02 \mathrm{~g} \cdot 100 \mathrm{~g}^{-1} \mathrm{~ms}\right)$ et le bore $\left(0,01 \mathrm{~g} \cdot 100 \mathrm{~g}^{-1} \mathrm{~ms}\right)$, les polyphénols $\left(76,6 \mathrm{mg} \cdot 100 \mathrm{~mL}^{-1}\right)$ et les caroténoïdes $\left(70 \mu \mathrm{g} \cdot \mathrm{mL}^{-1}\right)$. Il contient de bonnes quantités de vitamine $\mathrm{C}$ $\left(38,77 \mathrm{mg} \cdot 100 \mathrm{~mL}^{-1}\right)$ et il pourrait être une source potentielle d'acides aminés essentiels tels que l'isoleucine, la valine et le tryptophane $\left[\left(4,2,3,9\right.\right.$ et 3,9) $\mathrm{g} \cdot 100 \mathrm{~g}^{-1}$ de protéines] dont les teneurs se révèlent plus élevées que celles recommandées par le groupe FAO / OMS / UNU. En outre, il contient une faible quantité d'huile $\left(1,1 \mathrm{~g} \cdot 100 \mathrm{~g}^{-1} \mathrm{~ms}\right)$. Conclusion. Le jus des fruits de Physalis devrait capter un grand intérêt du fait de sa composition. Ses qualités nutraceutiques potentielles pourraient contribuer à classer le Physalis au rang de culture commerciale. Certaines molécules telles que des molécules antimicrobiennes et des withanolides bioactives qui ont des effets ethnomédicaux et médicaux connus devront encore être étudiés dans le jus de Physalis.

Égypte / Physalis pubescens / fruits / composition globale / teneur en éléments minéraux / teneur en protéines / teneur en lipides / caroténoïde / acide ascorbique /

polyphénol
Fruits, 2010, vol. 65, p. 255-265 (C) 2010 Cirad/EDP Sciences All rights reserved DOI: 10.1051/fruits/2010021 www.fruits-journal.org

RESUMEN EsPaÑoL, p. 265 


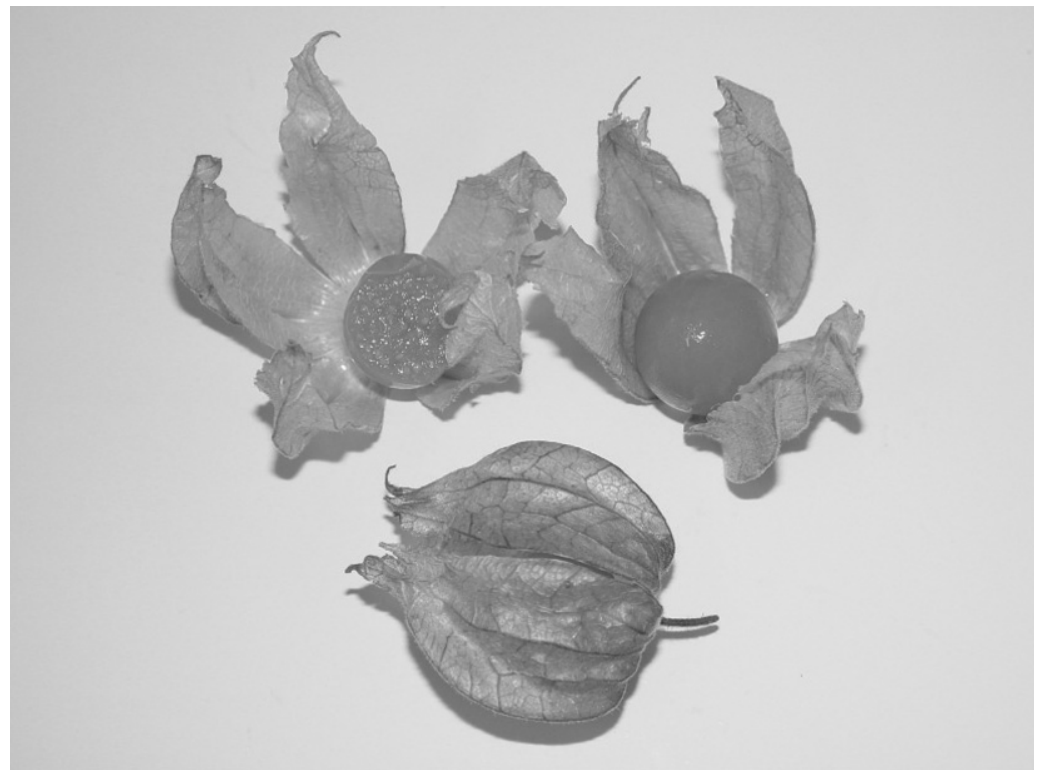

Figure 1. Fruit of Physalis pubescens L. (Photo A. El Sheikha). tangy, resembling a Chinese lantern [4]. It is fairly adaptable to a wide variety of soils, light (sandy), loamy and clay, and requires well-drained soil. It can grow in semi-shade or no shade, and dry or moist soil. So, Physalis can be sown in arid environmental conditions and people may be encouraged to propagate it in new reclaimed lands, especially the desert regions ${ }^{1}$. A single plant may yield up to (0.5 to 1.1$) \mathrm{kg}$ of fruits and carefully tended plants can provide high production $\left(12 \mathrm{t} \cdot \mathrm{ha}^{-1}\right)$; the total production of Egypt rose to $1000 \mathrm{t}$ in 2006 [5].

Physalis is included in the priority list of many governments' horticulture and fruit export plans. It is relatively unknown in importing markets and remains an exotic fruit. It is exported from several countries including Colombia, Egypt, Zimbabwe, Kenya, Madagascar, South Africa and Southeast Asia, but Colombia stands out as one of the largest producers, consumers and exporters. Physalis occupies the second position in the priority list of 15 exportable fruits; exports of this crop in 2004 were worth $14 \mathrm{M}^{\mathrm{SUS}}{ }^{2}$.

Many medicinal properties have been attributed to Physalis as a whole plant, including antipyretic, depurative, diuretic, pectoral and vermifuge. The plants were formerly highly prized by Arab physicians as a medical plant for treating kidney diseases (as it purportedly disintegrated kidney stones) and urinary passage diseases. Recently, many studies have described the therapeutic applications and the pharmacological activity of the Physalis species as anti-parasitic, anti-viral, anti-neoplasic, antioxidant and anti-leukemic [6, 7].

Peoples in many parts of the world usually know Physalis in their countries, but the potential of this fruit for intensive cultivation

${ }^{1}$ Randall R.P., Plant database, a comprehensive database of plant information, Dep. Agric., W. Aust., available at: http:// www.hear.org/gcw/html/autogend/ datasources.htm (access. Dec. 2001).

2 The Bayer Crop Science Magazine for Modern Agriculture, available at: http:// www.bayercropscience.com (access. Sep. 2006). 
has just begun to be explored. One of the challenges of recent years has been to participate in the development of Physalis as a commercial crop of economic utility. Previous work on Physalis has focused on the general proximate composition of the fruit, which was used as an excellent source of niacin [8], and determination of the geographical origin of Physalis by biological fingerprint [9]. Thereafter, isolation and characterization of several bioactive withanolides from the whole plant of other species of Physalis were reported by certain authors [10]. In order to obtain better knowledge of the nutraceutical properties and medicinal characteristics of the Physalis fruits cultivated in Egypt, we determined the biochemical, oil and mineral compositions of the raw juice extracted from Physalis pubescens.

\section{Materials and methods}

\subsection{Fruit of Physalis pubescens or Physalis}

Ripe Physalis pubescens L. fruits were obtained in May 2008 from local growers in Arab El-Rawshda village, Toukh, Qalyoubia Governorate, which is one of the Delta Governorates located in the north of Egypt. Intact fruits were carefully selected according to the degree of ripeness measured by fruit color (brilliant orange). The whole fresh fruits of Physalis pubescens were sent by plane from Egypt to the laboratory (CIRAD, Montpellier, France) where they were studied; they were preserved at $-20^{\circ} \mathrm{C}$ for the duration of the experiment.

\subsection{Juice extraction}

Physalis fruits were de-husked manually, sorted to select the ripe and intact ones, graded depending mainly on their color, and washed. Then, the fruits were pulped by using a fruit pulper (Braun, Model 2001, Germany) for juice extraction. Juice was filtered on cheesecloth to separate seeds and skins and the fresh fruit juice was analyzed directly after production.

\subsection{Physicochemical properties and chemical composition of Physalis fruit juice}

Juice yield was calculated as the percentage of juice obtained from $100 \mathrm{~g}$ of fresh fruits [11]. The color of raw juice samples was assessed by using a Lovibond Tintometer (Model E, Salisbury, Great Britain, UK) [12].

Moisture, crude protein $(\% \mathrm{~N} \times 6.25)$ and total ash were determined [13]. pH was measured at $25^{\circ} \mathrm{C}$. Total acidity was titrated with $0.1 \mathrm{~N} \mathrm{NaOH}$ using a phenolphthalein indicator, then it was expressed as anhydrous citric acid per $100 \mathrm{~g}$ of sample. Ascorbic acid was estimated by the colorimetric method of Folin-Ciocalteu at $760 \mathrm{~nm}$ [14]. Total polyphenolic substances were colorimetrically measured (as tannic acid) at $640 \mathrm{~nm}$ by Folin-Ciocalteu's method [15]. The total carotenoid content was determined in $80 \%$ acetone extract and measured spectrophotometrically at $440 \mathrm{~nm}$ as $\left(\mu \mathrm{g} \cdot \mathrm{mL}^{-1}\right)$ [13]. Pectin substance content was determined as calcium pectate and multiplied by the conversion factor $(x$ 100/102) according to the method described by Egan et al. [16]. Thirteen important minerals were analyzed. Total phosphorus was determined colorimetrically at $660 \mathrm{~nm}$ [17], and sodium and potassium contents were estimated by flame photometer (Jenway PFP 7, GB). Other minerals were determined by atomic spectrophotometer (Perkin Elmer 932AA, Australia). The [sugar / acid] ratio was calculated as [total soluble solids / titratable acidity] ${ }^{3}$ [18]. The measurement of Brix degree was carried out using an Abbe refractometer at $20^{\circ} \mathrm{C}$, graduated in \% (Carl Zeiss, Germany).

3 Lacey K., McCarthy A., Foord G., Maturity testing of citrus, Dep. Agric., W. Aust., Available at: http://www.agric.wa.gov.au/ agency/pubns/farmnote/2000/f00300.htm (access. Dec. 2001). 


\subsection{Total sugar content}

\subsubsection{Extraction of sugars under reflux} of ethanol $80 \%$ [19]

Five $\mathrm{g}$ of samples were agitated in $100 \mathrm{~mL}$ ethanol $80 \%$ before being kept under reflux of ethanol for $1 \mathrm{~h}$. The insoluble residue was reintroduced into $100 \mathrm{~mL}$ ethanol $80 \%$ and the extraction was carried out a second time for $1 \mathrm{~h}$. The insoluble residue was rinsed with ethanol $80 \%$. The ethanol was eliminated at $45^{\circ} \mathrm{C}$ with a rotary evaporator until (15 to 20 ) $\mathrm{mL}$ extract was obtained, which was adjusted to $50 \mathrm{~mL}$ with pure water before being filtered to $0.2 \mathrm{~mm}$ for chromatographic analysis.

\subsubsection{Dosage of mono- and disaccharides by ionic chromatography [20]}

The solution of raw Physalis juice was diluted to obtain a concentration for each sugar ranging between $(5$ and 30$) \mathrm{mg} \cdot \mathrm{L}^{-1}$. A quantity of $0.8 \mathrm{~mL}$ of filtered or centrifuged solution was poured into a tube adapted to the automatic sampling machine. Separation was carried out on an ion chromatograph (Dionex DX600) equipped with a column filled with balls of polystyrene-divinyl-benzene from ( 5 to 10$) \mu \mathrm{m}$ with an anion-exchange column (Dionex CarboPac PA1; $250 \mathrm{~mm} \times 4 \mathrm{~mm}$ ) and with an amperometric detector (PAD).

\subsection{Polyphenols fractionated by HPLC}

Polyphenols extracted from raw juice were fractionated by HPLC (HP 1100, Germany) under the following conditions: injection volume10 $\mu \mathrm{L}$; column: Hypersil BDS-C18, $5 \mu \mathrm{m}(150 \mathrm{~mm} \times 4.6 \mathrm{~mm}$, Altech, USA); UV detector at $254 \mathrm{~nm}$; mobile phase: solvent A: [acetic acid / acetonitrile] (0.5/99.5, v / v) and solvent B: [acetic acid / distilled water $(0.5 / 99.5, \mathrm{v} / \mathrm{v})$ with a flow rate of $0.3 \mathrm{~mL} \cdot \mathrm{min}^{-1}$ at $25^{\circ} \mathrm{C}$. The standard curve was prepared by mixing equal weights of pyrogallic, hydroquinone, resorcinol, catechin, phenol, rutin, myricetin, quercetin, kaempferol and gallic, protocatechuic, parahydroxybenzoic, chlorogenic, vanillic, paracoumaric, ferulic, salicylic, ortho-coumaric, coumaric, and cinnamic acids.

\subsection{Amino acid analysis}

Amino acid compositions were determined on a Beckman Amino Acid Analyzer 119 CL (GB) [21] after hydrolysis with $6 \mathrm{~N} \mathrm{HCl}$ containing $0.1 \%$ mercaptoethanol at $100{ }^{\circ} \mathrm{C}$ for $24 \mathrm{~h}$. Tryptophan was quantified on a $\mathrm{Ba}(\mathrm{OH})_{2}$ hydrolyzate by the colorimetric method [22].

\subsection{Determination of Oil content in the juice}

Twenty g of raw Physalis juice was poured into a 1-L separating funnel and was agitated with $100 \mathrm{~mL}$ hexane. The lower aqueous phase was collected then re-extracted with hexane three times. The hexane phases were collected and washed with distilled water three times. The total hexane phase was then dried with anhydrous sodium sulfate, and then concentrated with a rotary evaporator. After distillation of hexane and elimination of the last traces under a nitrogen flow, the total lipid content was obtained by weighing.

\subsection{Fatty acid composition and calculation of iodine index}

\subsubsection{Preparation of fatty acid methyl esters (FAME)}

The triglycerols were methylated directly into methyl esters. In a $25-\mathrm{mL}$ round-bottom flask, $10 \mathrm{mg}$ of extracted oil were added to $3 \mathrm{~mL}$ sodium methylate solution containing phenolphtalein [23]. The reaction mixture was refluxed for $10 \mathrm{~min}$ and $3 \mathrm{~mL}$ methanolic $\mathrm{HCl}$ were added until phenolphtalein discoloration; the mixture was then refluxed again for $10 \mathrm{~min}$ and cooled to room temperature. Hexane $(8 \mathrm{~mL})$ and $10 \mathrm{~mL}$ water were added. The organic phase was recovered, dried over anhydrous sodium sulfate and filtered for subsequent GC analysis. 


\subsubsection{FAME analysis}

The FAME analysis was performed by GC (Agilent, Model GC 6890) equipped with a flame-ionization detector (FID). A Supelcowax 10 capillary column (SGE, Courtaboeuf, France; $0.32 \mathrm{~mm}$ internal diameter $\times 30 \mathrm{~m}$ long, $0.25 \mu \mathrm{m}$ film thickness) was used. Fatty acid methyl esters were directly injected into the GC. The carrier gas was helium with a flow rate of $1 \mathrm{~mL} \cdot \mathrm{min}^{-1}$, and splitting ratio of $1 / 100$. The injector temperature was $250{ }^{\circ} \mathrm{C}$ and that of the FID was $270{ }^{\circ} \mathrm{C}$. Fatty acids were identified by comparison with commercially available fatty acid standards.

The iodine index was calculated from the unsaturated fatty acid content of the oil determined by CPG.

\section{Results and discussions}

\subsection{Dry matter content and Brix degree of Physalis fruit juice}

The raw Physalis juice had [(10.66 \pm 0.14$) \%]$ dry matter, which was higher than cantaloupe juice (8.5\%) [24] and lemon juice $(9.3 \%)^{4}$, but this dry matter was lower than that of fresh orange juice (11.7\%) and mango juice (19.1\%) [25]. Physalis juice had $(10.7 \pm 0.10)^{\circ}$ Brix, which was higher than that of fresh cantaloupe juice $\left(8.4^{\circ}\right.$ Brix) [24], while it was lower than that reported for fresh mango juice (18.2 ${ }^{\circ}$ Brix) [25].

\subsection{Physicochemical properties and chemical composition of Physalis fruit juice}

The dominant color fractions of fresh Physalis juice were yellow and red (table I). This type of color was also found for Physalis peruviana [26], Physalis ixocarpa [27] and Physalis pruinosa [28]. The $\mathrm{pH} 3.54$ (table I) of the fresh juice was higher than citrus juices ( $\mathrm{pH} 2.3$ for lime and $\mathrm{pH} 2.4$ for lemon juices ${ }^{4}$ ), while it was close to that of orange juice ( $\mathrm{pH}$ 3.6) [29]. Its total titratable acidity reached $1.43 \%$ (table $I$ ). This was higher than that reported for lemon juice (1.15\%) [30] and cantaloupe juice (0.04\%) [31] but lower than that in two varieties of mango fruit juices (2.29\% and 4.11\%) [25]. Physalis fruit juice had a high [sugar / acid] ratio $(7.6 / 1)$ (table I); it was higher than that in fresh cantaloupe juice ([2.1/1] ratio) [24], while it was lower than that reported for fresh mango juice ([7.9/1] ratio) [25].

The fresh Physalis juice had very high carotenoid content $\left(70 \mu \mathrm{g} \cdot \mathrm{mL}^{-1}\right.$ on a wet weight basis) (table I). For example, cantaloupe juice contains only $7.6 \mu \mathrm{g} \cdot \mathrm{mL}^{-1}$ [24], lemon has $0.3 \mu \mathrm{g} \cdot \mathrm{mL}^{-1}$ and orange has $3.2 \mu \mathrm{g} \cdot \mathrm{mL}^{-1}$ (see footnote 4 ).

It contained a considerable amount of polyphenols (76.6 mg.100 $\mathrm{mL}^{-1} \mathrm{ww}$ ) as tannic acid (table I), which was lower than that of fresh apricot juice $\left(150.3 \mathrm{mg} \cdot 100 \mathrm{~mL}^{-1}\right)$ [3].

Ascorbic acid $\left(38.77 \mathrm{mg} \cdot 100 \mathrm{~mL}^{-1} \mathrm{ww}\right)$ contents (table I) were higher than those of cantaloupe $\left(37 \mathrm{mg} \cdot 100 \mathrm{~mL}^{-1}\right)$ and fresh apricot juices (21.75 mg $100 \mathrm{~mL}^{-1}$ ) [3], but it had lower content than lemon $\left(46 \mathrm{mg} \cdot 100 \mathrm{~mL}^{-1}\right)$ and orange juices $\left(50 \mathrm{mg} \cdot 100 \mathrm{~mL}^{-1}\right)^{4}$.

\subsection{Mineral composition of Physalis fruit juice}

Raw Physalis juice had high contents of potassium (1210 mg.100 g $\mathrm{g}^{-1}$ wet weight basis) and sodium (40 mg.100 $\mathrm{g}^{-1} \mathrm{ww}$ ) (table II). Potassium and sodium control the water balance of the body. For example, this raw Physalis juice potassium content was higher than the potassium content in lime, lemon and orange juices [(110, 120 and 200) $\left.\mathrm{mg} \cdot 100 \mathrm{~g}^{-1} \mathrm{ww}\right]^{4}$. The intake requirement for $\mathrm{K}$ is $4700 \mathrm{mg}$ per day ${ }^{5}$. The

\footnotetext{
${ }^{4}$ National Nutrient Database for Standard Reference, NDB No.09152, 09160 and 09206, USDA, Wash. D.C., 2006. Available at: http:// www.nal.usda.gov/fnic/foodcomp/cgi-bin/ list_nut_edit.pl 5

Dietary Reference Intakes "DRIs", Dietary reference intakes of nutrient-based reference values, established by Nutr. Board Ntl Acad. Sci., Ntl. Acad.Press, Wash. D.C, 2004. Available at: http://www.nap.edu
} 
Table I.

Physicochemical characteristics and chemical composition of Physalis pubescens fruit juice (values are means of three determinations \pm standard deviation).

(a) Physicochemical characteristics

Juice yield $\mathrm{pH}$ value

(\%)

Total titratable acidity (as anhydrous citric acid \%)

[Sugar / acid] ratio

$63.9 \pm 2.4$

$3.54 \pm 0.005$

$1.43 \pm 0.08$

\section{(b) Color parameters measured by Lovibond}

$\begin{array}{ccc}\text { Blue } & \text { Yellow } & \text { Red } \\ 2.1 \pm 0.02 & 35.0 \pm 0.04 & 6.6 \pm 0.01\end{array}$

(c) Chemical composition of Physalis juice content on a wet weight basis

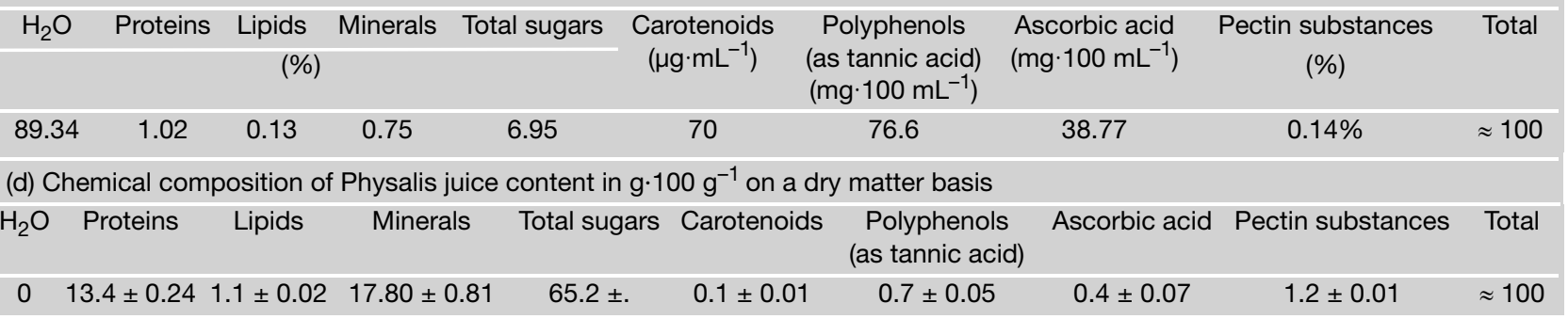

Physalis phosphorus content was (590 $\left.\mathrm{mg} \cdot 100 \mathrm{~g}^{-1} \mathrm{ww}\right)$, while that of lime, lemon and orange juices was (14, 6 and 17) $\mathrm{mg} \cdot 100 \mathrm{~g}^{-1} \mathrm{ww}^{4}$. The recommended intake is $700 \mathrm{mg}$ of phosphorus per day ${ }^{5}$.

The calcium content of Physalis juice (70 $\mathrm{mg} \cdot 100 \mathrm{~g}^{-1} \mathrm{ww}$ ) is higher than the calcium content of lime, lemon and orange juices $\left[\left(14,7 \text { and 11) } \mathrm{mg} \cdot 100 \mathrm{~g}^{-1} \mathrm{ww}\right]^{4}\right.$. Consumption of food rich in calcium (e.g., dairy products) is strongly recommended for people at risk: old people, diabetics, etc. The dietary recommended intake of calcium is $1000 \mathrm{mg}$ per day ${ }^{5}$. The magnesium content of Physalis fruit juice $\left(20 \mathrm{mg} \cdot 100 \mathrm{~g}^{-1} \mathrm{ww}\right.$ ) was higher than the magnesium content of lime, lemon and orange juices $[(8,6$ and 11) $\left.\mathrm{mg} \cdot 100 \mathrm{~g}^{-1} \mathrm{ww}\right]^{4}$. Magnesium consumption is often lower than that recommended [(300 to 400) mg per day $]^{5}$.

The zinc content of physalis juice (2 $\mathrm{mg} \cdot 100 \mathrm{~g}^{-1} \mathrm{ww}$ ) was higher than the zinc content of lime, lemon and orange juices $\left[(0.08,0.05 \text { and } 0.05) \mathrm{mg} \cdot 100 \mathrm{~g}^{-1} \mathrm{ww}\right]^{4}$. Zinc occurs in a wide variety of foods; it is relatively high in nuts, legumes and whole grain cereals but is lower in fruits and vegetables [32]. The recommended zinc intake is (8 to 11) $\mathrm{mg}$ per day ${ }^{5}$. The copper content of Physalis juice $\left(1.5 \mathrm{mg} \cdot 100 \mathrm{~g}^{-1} \mathrm{ww}\right)$ was higher than the copper content of lime, lemon and orange juices [ $(0.027,0.029$ and $\left.0.044) \mathrm{mg} \cdot 100 \mathrm{~g}^{-1} \mathrm{ww}\right]^{4}$. Copper is an essential nutrient required by the human body in daily dietary amounts of $0.9 \mathrm{mg}$ per day $^{5}$. The iron content of raw Physalis juice $\left(1.2 \mathrm{mg} \cdot 100 \mathrm{~g}^{-1} \mathrm{ww}\right)$ was higher than the iron content of lime, lemon and orange juices $\left[(0.09,0.03 \text { and } 0.2) \mathrm{mg} \cdot 100 \mathrm{~g}^{-1} \mathrm{ww}\right]^{4}$. The recommended iron intake is ( 8 to 18) $\mathrm{mg}$ per day ${ }^{5}$. The manganese content of Physalis fruit juice $\left(1.2 \mathrm{mg} \cdot 100 \mathrm{~g}^{-1} \mathrm{ww}\right)$ was higher than the manganese content of lime, lemon and orange juices [(0.018, 0.008 and $\left.0.014) \mathrm{mg} \cdot 100 \mathrm{~g}^{-1} \mathrm{ww}\right]^{4}$. The recommended intake of manganese is (1.8 to 2.3 ) $\mathrm{mg}$ per day $^{5}$.

Furthermore, Physalis juice had a good level of boron $\left(1.1 \mathrm{mg} \cdot 100 \mathrm{~g}^{-1} \mathrm{ww}\right)$ compared with several consumed foods, such as bakery and meat products [33, 34]. The recommended intake of boron varies from [(1 to 13) mg per day] [35].

\subsection{Sugar composition of Physalis fruit juice}

The raw juice contained glucose $\left(2.28 \mathrm{~g} \cdot \mathrm{L}^{-1}\right)$, fructose $\left(2.31 \mathrm{~g} \cdot \mathrm{L}^{-1}\right)$ and sucrose $\left(2.81 \mathrm{~g} \cdot \mathrm{L}^{-1}\right)$ in quantities lower than those found in lime 
Table II.

Mineral composition of the juice (mg.100 g-1 wet weight basis) of Physalis pubescens $\mathrm{L}$.

\begin{tabular}{ccccccccccc}
\hline Potassium & Phosphorus & Calcium & Sodium & Magnesium & Zinc & Copper & Iron & Manganese & Boron \\
\hline 1210 & 590 & 70 & 40 & 20 & 2 & 1.5 & 1.2 & 1.2 & 1.1
\end{tabular}

\begin{tabular}{|c|c|c|c|c|c|c|c|c|c|c|c|}
\hline $\begin{array}{l}\text { Protocatechic } \\
\text { acid }\end{array}$ & $\begin{array}{c}\text { Para- } \\
\text { hydroxybenzoic } \\
\text { acid }\end{array}$ & $\begin{array}{c}\text { Chlorogenic } \\
\text { acid }\end{array}$ & Catechin & Phenol & $\begin{array}{l}\text { Vanillic } \\
\text { acid }\end{array}$ & $\begin{array}{l}\text { Para- } \\
\text { coumaric } \\
\text { acid }\end{array}$ & $\begin{array}{l}\text { Ferulic } \\
\text { acid }\end{array}$ & $\begin{array}{l}\text { Salicylic } \\
\text { acid }\end{array}$ & Rutin & $\begin{array}{l}\text { Coumaric } \\
\text { acid }\end{array}$ & Myricetin \\
\hline 9.32 & 5.61 & 20.86 & 49.68 & 156.05 & 27.27 & 53.68 & 100.36 & 73.41 & 4.49 & 1.76 & 1.04 \\
\hline
\end{tabular}

juice $\left(6 \mathrm{~g} \cdot \mathrm{L}^{-1}\right.$ glucose, $6.1 \mathrm{~g} \cdot \mathrm{L}^{-1}$ fructose and $4.8 \mathrm{~g} \cdot \mathrm{L}^{-1}$ sucrose $)^{4}$. The total sugar content (glucose + fructose + sucrose) of Physalis juice was $7.4 \mathrm{~g} \cdot \mathrm{L}^{-1} \mathrm{ww}$. This content is lower, for example, than that found in lime juice $\left(16.9 \mathrm{~g} \cdot \mathrm{L}^{-1}\right)^{4}$.

\subsection{Polyphenol composition of Physalis fruit juice}

Twelve phenolic fractions were identified in the methanolic extract of Physalis juice (table III). The major phenolic compounds in the fresh juice were catechin, salicylic, para-cumaric and chlorogenic acids. The predominant compounds were phenols followed by ferulic acid. On the other hand, El Sheikha et al. [2] stated that the major compounds of fresh apricot juice phenolic fractions were ferulic, salicylic and chlorogenic acids, where the predominant compound was resorcinol.

\subsection{Amino acids and protein content of Physalis fruit juice}

The amino acid analysis of Physalis juice showed that the amounts of essential amino acids such as isoleucine, leucine, lysine, threonine, tryptophan and valine were higher than those recommended by the FAO / WHO / UNU [36] (table IV). Alanine, aspartic acid, glutamic acid, glycine and proline were the major amino acids (table IV). Its protein content was low (1.02\% as ww, table II) but it had a high nutritional value compared with egg protein because of its relatively high content in essential amino acids and its good digestibility. Protein content was higher than that of cantaloupe (0.69\%) [24], lemon (0.38\%) and orange juices $(0.70 \%)^{4}$.

\subsection{Oil content and fatty acid composition of the oil extracted from Physalis juice}

The oil content of Physalis fruit juice was low (1.1 g.100 g ${ }^{-1}$ dry matter basis) but this content is equivalent to citrus fruit juices such as orange juice $(1.7 \%)^{4}$. The total content of unsaturated and polyunsaturated fatty acids of Egyptian Physalis oil was $65.5 \%$. This, however, is less than in corn $85.5 \%$ or olive oils $83.4 \%$ (table V). The study of fatty acid composition shows the following elements:

- Oleic acid C18:1 n-9 is present in much greater quantity (23.42\%) in Physalis oil than in oil of raw juices of grapefruit $(0.1 \%)$, passion fruit $(0.2 \%)$ and orange $(0.3 \%)^{4}$. The amount of linoleic acid C18:2 n-6 was lower (5.47\%) than in corn oil (53\%) and olive oil (9\%) but there was a high level of linolenic acid C18:3 n-3 in the oil of Physalis juice (26.98\%).

- One of the important technological characteristics of this oil is the absence of shortchain fatty acids such as hexanoic acid C6:0 and caprylic C8:0 that could explain the absence of unpleasant odor of Physalis pubescens juice. 


\begin{tabular}{|c|c|c|c|c|}
\hline \multirow[t]{2}{*}{ Amino acids } & \multirow[t]{2}{*}{ Content } & \multicolumn{3}{|c|}{ FAO's recommendations } \\
\hline & & Child 2-5 years & Child $10-12$ years & Adult \\
\hline Isoleucine & 4.236 & 2.8 & 2.8 & 1.3 \\
\hline Leucine & 4.968 & 6.6 & 4.4 & 1.9 \\
\hline Lysine & 4.762 & 5.8 & 4.4 & 1.6 \\
\hline Cysteine & 1.291 & - & - & - \\
\hline Methionine & 1.694 & - & - & - \\
\hline Total sulfur-containing amino acids & 2.985 & 2.5 & 2.2 & 1.7 \\
\hline Tyrosine & 1.066 & - & - & - \\
\hline Phenylalanine & 2.585 & - & - & - \\
\hline Total aromatic amino acids & 3.651 & 6.3 & 2.2 & 1.9 \\
\hline Threonine & 3.377 & 3.4 & 2.8 & 0.9 \\
\hline Tryptophan & 3.893 & 1.1 & 0.9 & 0.5 \\
\hline Valine & 3.927 & 3.5 & 2.5 & 1.3 \\
\hline Total essential amino acids & 31.799 & 32.0 & 22.2 & 11.1 \\
\hline Histidine & 3.223 & - & - & - \\
\hline Arginine & 2.787 & - & - & - \\
\hline Aspartic acid & 14.469 & - & - & - \\
\hline Glutamic acid & 13.185 & - & - & - \\
\hline Serine & 3.545 & - & - & - \\
\hline Proline & 18.296 & - & - & - \\
\hline Glycine & 5.532 & - & - & - \\
\hline Alanine & 7.163 & - & - & - \\
\hline Total non-essential amino acids & 68.20 & - & - & - \\
\hline
\end{tabular}

Table V.

Centesimal fatty acid composition (oil\%) of the oil of Physalis pubescens juice compared with that obtained for olive oil [39] and corn oil [40].

\begin{tabular}{|c|c|c|c|c|c|c|c|c|c|c|c|c|c|c|c|c|c|}
\hline Oil type & C10:0 & C12:0 & C14:0 & C15:0 & C15:1 & C16:0 & C16:1 & C17:0 & C18:0 & $\begin{array}{l}\text { C18:1 } \\
(n-9)\end{array}$ & $\begin{array}{c}\text { C18:1 } \\
(n-7)\end{array}$ & $\begin{array}{c}\text { C18:2 } \\
(n-6)\end{array}$ & $\begin{array}{l}\text { C18:3 } \\
(n-3)\end{array}$ & C20:0 & C20:1 & Total & Unsaturated \\
\hline $\begin{array}{l}\text { Physalis } \\
\text { juice }\end{array}$ & 1.95 & 1.91 & 1.27 & 0.41 & 0.46 & 23.27 & 1.53 & 0.37 & 4.81 & 23.42 & 6.85 & 5.47 & 26.98 & 0.54 & 0.77 & 100 & 65.5 \\
\hline Olive & $\mathrm{nd}^{*}$ & nd & nd & - & - & 13.8 & 1.4 & - & 2.8 & 72 & - & 9.0 & 1.0 & nd & - & 100 & 83.4 \\
\hline Corn & nd & nd & 0.0 & - & - & 11.7 & 0.1 & - & 2.2 & 31.6 & - & 53.0 & 0.8 & 0.4 & - & 100 & 85.5 \\
\hline
\end{tabular}

- The iodine index of Egyptian Physalis juice oil was 112.3. This iodine index is rather high if we compare it with palm oil (56.9) [37], sunflower oil (90.0) [38], olive oil (81.3) [39] and almond oil (100.3) [37]. It is lower than that of unsaturated oils such as corn oil (120.5) [40]. This is due to its high proportion of unsaturated fatty acids such as oleic acid (23.42\%) and linolenic acid (26.98\%). 


\subsection{Summary chart of Physalis pubescens juice composition}

The results obtained were compiled to give a summary of Physalis pubescens juice composition (table I).

\section{Conclusions}

Tropical pulpy juices play an important role in nutrition as an excellent base for low-calorie and dietetic products. Physalis juice should attract great interest because of its nutritional properties. It has remarkable agronomic potential that has not fully been appreciated. The development of adequate agro-technical and storage practices could make this fruit a promising new crop for arid regions. The juice of Physalis pubescens fruit will keep for some time its health-giving and curing secrets. Quite a full analysis of the composition of Physalis fruit juice was done. Physalis juice contains a low amount of oil (1.1 g.100 g $\mathrm{g}^{-1}$ dry matter basis). This oil contains a high proportion of unsaturated fatty acids $(65.5 \%)$ including $32.5 \%$ polyunsaturated fatty acids. The absence of short-chain fatty acids such as hexanoic acid C6:0 and caprylic C8:0 could explain the absence of unpleasant odor of the juice. Physalis fruit juice is nutritious, containing particularly high levels of phenolic compounds, carotenoids and all the important minerals for the body: Cu, B, P, Mn, Zn, K, Fe and Ca. The juice contains a good amount of proteins (13.4 $\mathrm{g} \cdot 100 \mathrm{~g}^{-1} \mathrm{dm}$ ) and could be a good potential source of essential amino acids except for Tyr, Phe, Leu and Lys. All these results and its potential nutraceutical quality could participate in the development of Physalis as a commercial crop of economic utility. However, certain molecules such as antimicrobial molecules and bioactive withanolides, which have the famous ethnomedical and medical effects of Physalis juice, still have to be studied.

\section{References}

[1] El Sheikha A.F., Zaki M.S., Montet D., Larroque M., Pelissier Y., Cerise de Terre
(Physalis pubescens L.), in: 10th Int. Symp. Aromatherapy and Medicinal Plants (Poster), Grasse, France, 2008.

[2] El Sheikha A.F., Zaki M.S., Bakr A.A., El Habashy M.M., Montet D., Physicochemical properties and biochemical composition of Physalis (Physalis pubescens L.) fruits, Food 2 (2) (2008) 124-130.

[3] El Sheikha A.F., Technological, chemical and microbiological studies on some packed foods, Fac. Agric., Minufiya Univ., Master Sci., Egypt, 2004, 174 p.

[4] El Sheikha A.F., Zaki M.S., Bakr A.A., El Habashy M.M., Montet D., Biochemical and sensory quality of Physalis (Physalis pubescens L.) juice, J. Food Proc. Preserv. (2009) 34 (2010) 541-555.

[5] Anon., Plant production statistics bulletin, Central Agency for Public Mobilization and Statistics (CAPMAS), Stat. Sect., Cairo, Egypt, 2001.

[6] El Sheikha A.F., Sainz de Los Terreros A., Nabet C., Montet D., Larroque M., Pelissier Y., Le Coqueret du Pérou (Physalis peruviana L.), in: 10th Int. Symp. Aromatherapy and Medicinal Plants (Poster), Grasse, France, 2008.

[7] El Sheikha A.F., Physalis fruits from paradise, in: Trace 5th Annu. Meet. Int. Conf. Trace in practice (New methods and systems for confirming the origin of food) (Poster), Freising, Germany, 2009.

[8] Watt B.K., Merrill A.L., Composition of foods, USDA, Agric. Handb. No. 8, 1963, 190 p.

[9] El Sheikha A.F., Condur A., Métayer I., Le Nguyen D.D., Loiseau G., Montet D., Determination of fruit origin by using $26 \mathrm{~S}$ rDNA fingerprinting of yeast communities by PCR-DGGE: preliminary application to Physalis fruits from Egypt, Yeast 26 (10) (2009) 567-573.

[10] Ahmed S., Yasmin R., Malik A., New withanolide glucosides from Physalis peruviana L., Chem. Pharm. Bull. 47 (1999) 477-480.

[11] Omar A.M., Technological studies on fruit juice concentrate, Fac. Agric., Zagazig Univ., Thesis, Egypt, 1998, 225 p.

[12] Ranganna S., Manual of analysis of fruit and vegetable products, 2 nd ed., Tata McGrowHill Publ. Co., Ltd., New Delhi, India, 1979, $634 \mathrm{p}$. 
[13] Anon., Official methods of analysis, Assoc. Off. Anal. Chem. (AOAC), 16th ed., Arlington V.A., USA, 1995.

[14] Bajaj K.L., Kaur G., Spectrophotometric determination of total ascorbic acid in vegetables and fruits, Analyst 106 (1981) 117120.

[15] Dóka O., Bicanic D., Determination of total polyphenolic content in red wines by means of the Folin-Ciocalteu colorimetry assay, Anal. Chem. 74 (2002) 2157-2161.

[16] Egan H., Kirk R.S., Sawyer R., Pearson's chemical analysis of foods, 8th ed., Churchill Livingstone, London, U.K., 1981, pp. 591.

[17] Taussky H.H., Shorr E., A micro-colorimetric method for the determination of inorganic phosphorus, J. Biol. Chem. 202 (1953) 675685.

[18] Fuleki T., Pelayo E., Palabay R.B., Carboxylic acid composition of varietal juice produced from fresh and stored apples, J. Agric. Food Chem. 43 (1995) 598-607.

[19] Anon., Procédure opérationnelle. Extraction des sucres au reflux d'éthanol à $80 \%$, Code: PC 0901A, Cirad Amis/Paa, Doc. Int., Montpellier, France, 2000, 6 p.

[20] Anon., Procédure opérationnelle. Dosage des mono et disaccharides par chromatographie ionique DX600, Code: PC 08A, Cirad Amis / Paa, Doc. Int., Montpellier, France, 2001, 7 p.

[21] Moore S., Stein W.H., Chromatographic determination of amino acids by the use of automatic recording equipment, in: Colowick S.P., Kaplan N.O. (Eds.), Methods in Enzymology, vol 6, Acad. Press, N.Y., U.S.A., 1963, pp. 819-831.

[22] Miller E.L., Determination of the tryptophan content in feeding stuffs with particular reference to cereals, J. Sci. Food Agric. 18 (1967) 381-386.

[23] Anon., Procédure opérationnelle. Préparation des esters méthyliques, Code: PC 019A, Cirad Amis / Paa, Doc. Int., Montpellier, France, 2005, 9 p.

[24] Moustufa B.M., Chemical and technological studies on some vegetables and fruits juices, Fac. Agric., Moshtohor, Zagazig Univ. (Benha Branch), Thesis, Egypt, 2002, 277 p.

[25] Zeid M.H.M., Technological studies on some fruit and vegetable products. Fac. Agric., Zagazig Univ., Thesis, Egypt, 1996, 265 p.
[26] Raghava R.P., Nisha R., Carotenoid content of husk tomato under the influence of growth regulators and gamma rays, Indian J. Plant Physiol. 33 (1990) 87-89.

[27] Cantwell M., Flores M.J., Trejo G.A., Developmental changes and post-harvest physiology of tomatillos fruits (Physalis ixocarpa L.), Sci. Hortic. 50 (1992) 59-70.

[28] Abou-Gharbia H.A., Abou-Tour E.M., Properties and processing of husk tomato, Minufiya J. Agric. Res. 26 (2001) 761-781.

[29] Carvalho L.M.J, Borchetta R., Silva É.M.M., Carvalho C.W.P., Miranda R.M., Silva C.A.B., Effect of enzymatic hydrolysis on particle size reduction in lemon juice (Citrus limon L.), cv. Tahiti, Braz. J. Food Technol. 9 (2006) 277-282.

[30] Joslyn M.A., Methods in food analysis, 2nd ed., Acad. Press Inc., Berkeley, Calif., USA, 1970.

[31] Galeb A.D.S., Wrolstad R..E., Mcdaniel M.R., Composition and quality of clarified cantaloupe juice concentrate, J. Food Proc. Pres. 26 (1) (2002) 39-56.

[32] Cousins R.I., Zinc, in: Zeigler E.E., Filer L.J. (Eds.), Present knowledge in nutrition, ILSI Press, Wash. D.C., U.S.A., 1996, 293 p.

[33] Hunt C., Herbei J., Effects of dietary boron on calcium and mineral metabolism in the streptozotocin-injected, vitamin D3-deprived rat, Magnes. Trace Elem. 10 (1991) 387-408.

[34] Anderson D., Cunningham W., Lindstrom T., Concentrations and intakes of $\mathrm{H}, \mathrm{B}, \mathrm{S}, \mathrm{K}, \mathrm{Na}$, $\mathrm{Cl}$, and $\mathrm{NaCl}$ in foods, J. Food Compos. Anal. 7 (1994) 59-82.

[35] Wardlaw G.M., Kessel M.W., Minerals, in: Lynne M.M.(Ed.), Perspectives in nutrition, 5th ed., McGraw-Hill Publ. Co., Ltd., Int. Ed., N.Y., U.S.A., 2002.

[36] Anon., Energy and protein requirement, Rep. Joint FAO / WHO / UNU (Food Agric. Organ. / World Health Organ. / U. N. Union) Meet. Ser. No. 724, WHO, Geneva, Switz., 1985.

[37] Itoh T., Tamura T., Matsumoto T., Sterols and methylsterols in some tropical and subtropical vegetable oils, Oléagineux 5 (1974) 253258.

[38] Pérez-Galvez A., Garrido-Fernandez J., Minguez-Mosquera I.M., Effect of high-oleic sunflower seed on the carotenoid stability of ground paper, J. Am. Oil Chem. Soc. 77 (2000) 79-83. 
[39] Kamal-Eldin A., Andersson R.A., Multivariate study of the correlation between tocopherol content and fatty acid composition in vegetable oils, J. Am. Oil Chem. Soc. 74 (1997) 375-380.
[40] Gordon M.H., Miller L.A.D., Development of steryl ester analysis for the detection of admixtures of vegetable oils, J. Am. Oil Chem. Soc. 74 (1997) 505-510.

\section{Composición principal de Physalis (Physalis pubescens L.) de jugo de frutos procedentes de Egipto.}

Resmuen - Introducción. La Physalis (cereza de tierra) es conocida desde hace mucho en Egipto. Es un fruto muy prometedor entre el conjunto de los frutos tropicales poco explotados. Recientemente, la importancia económica de la Physalis aumentó debido a su buena aceptación en el consumo local y a su gran éxito en África, en Latinoamérica y en los mercados europeos. Uno de los retos en estos últimos años fue el de posicionar la Physalis en el rango de cultivo comercial de utilidad económica. Con el fin de comprender las características nutraceúticas y médicas de los frutos de la Physalis cosechada en Egipto, estudiamos la composición bioquímica del jugo bruto de los frutos de $P$. pubescens. Material y métodos. Se conservaron frutos frescos enteros de $P$. pubescens de Egipto a $-20{ }^{\circ} \mathrm{C}$ durante la duración del experimento. El jugo se extrajo con la ayuda de un despulpador de frutos, luego se filtró sobre gasa para separar semillas y piel. Los contenidos en aceites, ácidos grasos, proteínas, aminoácidos, azúcares y minerales de los jugos se evaluaron, compararon y discutieron en relación con la composición bioquímica de otros frutos y aceites vegetales. Resultados. El rendimiento en jugo de los frutos de P.pubescens fue elevado (64\%); es rico en minerales como el potasio (11.32 $\left.\mathrm{g} \cdot 100 \mathrm{~g}^{-1} \mathrm{~ms}\right)$, el fósforo $\left(5.55 \mathrm{~g} \cdot 100 \mathrm{~g}^{-1} \mathrm{~ms}\right)$, el cinc $\left(0.02 \mathrm{~g} \cdot 100 \mathrm{~g}^{-1} \mathrm{~ms}\right)$ y el boro $\left(0.01 \mathrm{~g} \cdot 100 \mathrm{~g}^{-1} \mathrm{~ms}\right)$, los polifenoles $\left(76.6 \mathrm{mg} \cdot 100 \mathrm{~mL}^{-1}\right)$ y los carotenoides $\left(70 \mu \mathrm{g} \cdot \mathrm{mL}^{-1}\right)$. Contiene grandes cantidades de vitamina $\mathrm{C}$ $\left(38.77 \mathrm{mg} \cdot 100 \mathrm{~mL}^{-1}\right)$ y podría ser fuente potencial de aminoácidos esenciales, tales como la isoleucina, la valina y el triptófano $\left[\left(4.2,3.9\right.\right.$ et 3.9) $\mathrm{g} \cdot 100 \mathrm{~g}^{-1}$ de proteínas], cuyos contenidos se muestran más elevados que aquéllos recomendados por el grupo FAO /OMS /UNU Además, contiene escasa cantidad de aceite ( $\left.1.1 \mathrm{~g} \cdot 100 \mathrm{~g}^{-1} \mathrm{~ms}\right)$. Conclusión. El jugo de frutos de Physalis debería captar un gran interés debido a su composición. Sus cualidades nutracéuticas potenciales podrían contribuir a clasificar la Physalis en el rango del cultivo comercial. Ciertas moléculas, tales como las moléculas antimicrobianas de los withanolides bioactivos, que tienen efectos etnomedicales y medicales conocidos, deberían estudiarse aún en el jugo de Physalis.

Egipto / Physalis pubescens / frutas / composición aproximada / contenido mineral / contenido proteico / contenido de lípidos / carotinoides / ácido ascórbico / polifenoles 